\title{
TRANSLATIONS OF “DIWAN LUGAT-AL-TURK”
}

\section{Z.I. Sattorova}

Basic Doctoral Student Of The Department Of Classical Philology And Literary, Tashkent State University Of Oriental Studies

\section{ABSTRACT}

Mahmud Kashgari's "Diwan lugat-al-turk" is a very unique encyclopedic source and has about 30 translations and publications. Especially in recent years, the full translation of the work into Russian and Kyrgyz, as well as the publication of new editions in Uzbek in 2016 and 2017, form the basis of new research on the divan. This article analyzes translations and editions of the work in foreign and Uzbek languages.

KEYWORDS: - Encyclopedia, edition, colophon, original, libris, diwan, frame, conversion, copy.

\section{INTRODUCTION}

Mahmud Kashgari was one of the great figures of Central Asian early medieval culture, famous in the field of linguistics, especially in the field of Turkic languages, and left an indelible mark on history.

Alloma is one of the brightest representatives of the early medieval Renaissance. Based on the study of a wide variety of materials collected in his Diwanu lug'ati-t-turk, most scholars consider Kashgari to be the greatest Turkologist who made an invaluable contribution to the development of linguistics, ethnology, geography, literature, history and other sciences. In other words, Kashgari is an encyclopedic scholar, and Diwan is an encyclopedic intellectual product of the Renaissance[1]. He raised the humanistic knowledge of the Middle East to a higher level. At a time when his predecessors were studying Arabic grammar, which was the language of the Qur'an and science at the time, Mahmud Kashgari was one of the first to choose Turkish as the object of his research, even though Turkish was only the language of everyday life of the Turkic peoples. Devonu lug'ati-t-turk for the first time presented a vocabulary of Turkic languages, so we have the right to call the work a dictionary [2]. During his lifetime, the Samanids were replaced by the Qarakhanid dynasty in Movarounnahr, and the Turkic literary language became a widespread tradition in the region. Even in the centers of the Abbasid caliphate, in the lands inhabited by Arabs and other Samanids, the number of Turkic peoples increased and the Turkic language became more important. Mahmud Kashgari also completed his book "Diwanu lug'at al-turk" in 1075. The main text of the work was written in Arabic, which became the language of religion and science in the Muslim East, the whole Middle East at that time, and aimed to explain and teach the richness, content and diversity of the Turkic language.

\section{Literature review}

One of the most important and comprehensive works on the diwan in recent years has been the research of well-known Turkish scholars Ahmet 
CURRENT RESEARCH JOURNAL OF PHILOLOGICAL SCIENCES 2(6): 21-28,

May 2021 DOI: https://doi.org/10.37547/philological-crjps-02-06-05

ISSN 2767-3758

(C)2021 Master Journals

\section{Crossref do) 8 Google}

Accepted07thJune, $2021 \&$ Published $12^{\text {th }} J u n e, 2021$

Bijam Ercilasun and Ziyat Akkoyunli[3]. (Dr. AB Erjilasun has published more than 20 books and about 80 scientific articles on Diwanian research. Dr. Ziyat Akkayunli has also published more than 30 scientific publications on Diwanu Dictionaryt-Turk [4]). An important aspect of the research is that the author of the work, the history of its writing and survival to date, the title, the interpretation of the text, the transcription and, most importantly, the errors in publications and translations are justified by comparison with the manuscript. In this regard, a student of A.B. Erjilasun, at the same time in 2019, Dr. F. Ersoy's article "I was caught in a book" was published. In the article, the scientist states that he wrote a didactic work entitled "Novel of Diwanu lugati-tturk " [5]. The astonishing aspect of the scholar was that during the publication of the book by A.B. Erjilasun and Z.Akkayunli "Kashgarli Mahmud - Divanu Lugati't-Turk (Introduction Metin - Translation - Notes - Dizin)" he will have the opportunity to read the work. He chooses the representatives of two epochs as heroes of the novel, that is, Ali Amir, who lived in Istanbul in 1912, and the works of two Turkologists as modern heroes. In the novel, the author describes the discovery of the diwan and the myths and facts associated with it[6].

\section{Materials AND METHODS}

The name of Ali Amir opened a new history of "Diwani lug'ati-t turk". In 1913, Amir Sahib, a fan of ancient and rare books in Istanbul, bought the diwan from Burhanbey without fully realizing its value. A woman who is a cousin of former Finance Minister Ahmed Nazif Pasha brings the worn-out book to Burhanbey. Before his death, the former minister, who died in 1905, had bequeathed the book to the woman and promised not to sell it for less than 30 liras even when she was in dire need [7]. Research on how the book fell into the hands of Nazif Pasha shows that after the diwan was copied by Abu Bakr Savi Damascus, one of the owners of the book whose name was added on the first page passed to Muhammad Khatib Daraya of Egypt. [8] The Turkish Sultan Yavuz Sultan Selim, who conquered Egypt, sent all the booty - riches and treasures, unique material and spiritual resources by water to the Topkapi Palace. Diwan thus came to Turkey from Egypt. Given that Nazif Pasha's ancestors ruled in the palace, there are speculations about the fate of the diwan. Currently, the only copy of Diwanu lug'ati-t-turk is kept in the Istanbul (Fatih) National Library under number 4189.

According to Islamic tradition, the diwan is based on the grammatical rules of the Arabic language. Many students believe that the work was written in Turkish on behalf of the diwan. However, the diwan was written to teach Turkish to the Arabs. Researcher T. Garipov points out that Kashgari's name, in the name of his father and grandfather, refers to the ninety-nine attributes of Allah according to Islamic naming norms. We find three such animals in the anthroponymic triad of the Diwanian author. Its creator humbly introduces himself at the beginning of his book: "Mahmud, the servant of God, the son of Hussein, al-Kashgari, the son of Muhammad." Here, Mahmud and Muhammad are based on a single Arabic stem, Hamida, while Hussein acts as a diminutive to the epithets "Hasan" - "handsome", "good" [9].

Mahmud Kashgari claimed that one of his ancestors was the Emir who conquered Bukhara, but he did not leave any clear information about it, so this information caused deep controversy.

It is a miracle that such a large book as Diwanu lug'ati-t-turk has survived to this day. As acknowledged above, the lack of information about the author of this work and the originality of the manuscript is unknown to us, probably 
CURRENT RESEARCH JOURNAL OF PHILOLOGICAL SCIENCES 2(6): 21-28,

May 2021 DOI: https://doi.org/10.37547/philological-crjps-02-06-05

ISSN 2767-3758

(C)2021 Master Journals

\section{Crossref do) 8 Google}

Accepted07thJune, 2021 \& Published 12 thJune, 2021

explained by the lack of politically motivated or relatively few copies of the work (it is noted that Diwan had 4 copies signed by Kashgari, but none of these copies have been found). Otherwise, this work would not have remained unknown until the early twentieth century.

To date, Diwanu lug'ati-t-turk has been translated and published in more than 20 languages. In particular, translations were made into Turkish, Uzbek, Chinese, Persian, Kyrgyz, Kazakh, Uyghur, English, Russian, German and Azerbaijani languages. The services of Uzbek scholars who have completed such a complex process as the translation of the Diwan are also recognized by Turkologists around the world.

Divan's English translation. In 1982-1985, the diwan was first translated into English and published in three volumes at Harvard University in the United States [8]. The English translation of the diwan, which was the result of the hard work of researchers Robert Dankoff and James Kelly, was translated into English on the basis of the manuscript. The translation was published in 3 volumes (Volume 1 316, Volume 2 381, Volume 3337 pages).

Robert Denkoff was born in 1941 in Rogester, New York. The future scientist will study Oriental languages at Columbia University as an adult. In 1964 he volunteered for Turkey. She teaches English. Denkof, an orientalist by profession, was fascinated by ancient Turkic monuments. For several years, Dankoff conducted research on the history, art and textual features of Turkish written monuments in Turkey. In 1971, he defended his PhD dissertation on the study of Turkish and Islamic monuments at Harvard University and received his doctorate. He then taught Oriental Studies, especially Turkic Studies, at Brandeis and Arizona Universities until he became a professor at the University of Chicago in 1979. [10]

In his scientific research, he studied the linguistic and artistic features of written monuments in the Ottoman Turkish language. He also studied Islamic-Turkish written monuments in Central Asia. The Turkologist was well aware of the theories of various religions, especially the Qur'an and hadith. Therefore, the Arabic terms in the Diwanian translation, passages from the Qur'an, and the rules for the analysis of Arabic grammar did not complicate the study of the Diwanian.

The authors of the translation have reconstructed many errors in the original translations and editions, omitting the two omitted words in the text by comparing them with the original. The discovery of Diwan provided valuable information about the owners with evidence. This research has also been widely used in recent years on the work of the diwan. In addition to Diwan, the Turkologist was able to translate such a masterpiece as "Qutadgu bilig" directly into English.

Diwan's Kyrgyz translation. The Diwanu lug'ati-tturk contains a lot of information about the Kyrgyz language and dialects. Therefore, Kyrgyz scientists are conducting a lot of research on the work. In recent years, the diwan has been fully translated into Kyrgyz and published [11]. This translation was made by Kyrgyz turkologists $\mathrm{T}$. Tokoev and K. The Koshmokovs made it the result of many years of scientific research. All three volumes of the translation were published in Bishkek in 2011, 2012 and 2013. Volume 1 is 906 , Volume 2 is 591, and Volume 3 is 678 pages [12].

Russian translations of Diwan. Diwanu lug'ati-ttuk has been translated into Russian three times by non-Russian Turkish scholars. The work was first fully translated into Russian by Uzbek scholar Alibek Rustamov. However, this translation was not published for many years. According to IV Kormushin, A. Rustamov completed a 1215-page Russian translation in 
CURRENT RESEARCH JOURNAL OF PHILOLOGICAL SCIENCES 2(6): 21-28,

May 2021 DOI: https://doi.org/10.37547/philological-crjps-02-06-05

ISSN 2767-3758

(C)2021 Master Journals

\section{Crossref do) 8 Google}

Accepted07thJune, $2021 \&$ Published $12^{\text {th }} J u n e, 2021$

1979 and submitted it to the publisher for publication [13]. Due to the political situation in the 80 s and 90 s of the twentieth century, the editing process took a long time and the publishing process came to a standstill. Finally, in 2010, under the direction of IV Kormushin, the first volume of A. Rustamov's Russian translation was published by Vostochnaya literatura [14]. The first volume is 462 pages, with the preface (15-20 pages) and the introductory part (21-25 pages) written by IV Kormushin. In this article, the researcher discusses the creation of the diwan, Kashgari personality, Turkish, German, Uzbek, Uyghur, Azerbaijani, English translations, the process of preparation of this translation for publication.

The author of the second Russian translation of Diwanu lug'ati-t-turk, Z.A. Avezovadir. In 2005, he was the first to publish a Russian translation in 1,000 copies at the Dyke Press in Almaty [15].

The third Russian translation was made by Azerbaijani scholar Ramiz Askar. In 2009, the publication was published in 4 volumes with an index[16]. Ramiz Askar's Azerbaijani and Turkish translations are highly valued by world turkologists.

Uzbek translations and publications. Abdurauf Fitrat was the first Uzbek researcher to conduct research on the diwan and in 1927 published a collection of "The oldest samples of Turkish literature [17]." After that, in 1960-1963, "Diwanu lug'atit turk" was first translated into Uzbek and published in full[18]. The author explains in the Diwanian preface: “... since we do not have the manuscript, we acted on the basis of a printed copy in our own translation (Diwanian translation) printed in Istanbul [18].

In recent years, the development of science, innovation, the publication of high-quality facsimile publications, new interpretations have created a need for future publications. Now S. Mutallibov's translation has become a unique source. The need for researchers for further publications has increased. For this reason, the supplemented and revised editions of Diwanu lug'atit turk were published.

In 2016, under the editorship of Doctor of Philology, Professor Hamidulla Dadaboev, MUMTOZ SOZ published the first volume of Diwanu lug'otit turk by Alibek Rustamov, Academician of the Russian Academy of Sciences, and Hamidulla Boltaboev, a well-known literary scholar, Doctor of Philology. The second and third volumes were also published in 2016 [19]. Doctor of Philology Hamidulla Boltaboev and Candidate of Philology Bakhtiyor Isabekov prepared the next parts for publication.

According to Boltabayev, the publication is based on Mutallibov's translation and publication, and his comments are mostly preserved. At the same time, some changes had to be made as a result of the comparison with the Diwanian manuscript. A.Rustamov compared S.Mutallibov's translation with the original and restored the omitted sentences, words and phrases and letters in the text. The general changes in the publication are mainly as follows:

- Page numbers of the original are printed (Kashgari pages are not numbered. Later digitized by librarians);

- Translation and transliteration of unverified verses, hadiths and some poems in Cyrillic;

- The poems in the divan are structured in Roman numerals;

- Articles are written from the new paragraph with a break;

- Letters with examples are highlighted in the chapters;

- The reading of words in the Arabic script is given in italics, in square brackets in the form of words, phrases [example], which are acquired by the demand for content; 
CURRENT RESEARCH JOURNAL OF PHILOLOGICAL SCIENCES 2(6): 21-28,

May 2021 DOI: https://doi.org/10.37547/philological-crjps-02-06-05

ISSN 2767-3758

(C)2021 Master Journals

\section{Crossref do) 8 Google}

Accepted07thJune, $2021 \&$ Published $12^{\text {th }} J u n e, 2021$

- The word "horses" in the translation of S. Mutallibov has been changed to "names".

The first volume consists of 346 pages. The text is printed in Cyrillic, the cover is a picture of Mahmud Kashgari in Urumqi, a statue of Istanbul, and the inside of the cover is a geographical map of the "circle" drawn by Kashgari himself. Instead of the foreword there is a large article by $\mathrm{H}$. Boltaboev "The beginning of scientific literature". The article consists of the following subheadings: Literary sources of the Karakhanid period; Life and work of Mahmud KASHGARI; Dictionary author; Geography of the place and sources of "Diwan..."; Copies of Diwan...; Translations and Publications; Indexes and dictionaries based on the work; History of study; Reasons and features of the work; Contents; Scope of coverage; About this publication.

Following the comments on the transcriptions and symbols used in the publication, there is an introductory part of the diwan and a basic dictionary. At the end of the work, Mutallibov's comments on the tribes and clans mentioned in the divan, cities and some famous horses are added. Also, photocopies of the title pages of the well-known editions of "Diwanu lug'oti-t-turk" are chronicled.

The total volume of the second volume is 286 pages. Inside the cover is a Russian translation of Kashgari's hand-drawn "circle" from the Almaty edition. The work begins with the preface "From the Publisher: About the Second Volume Edition." This article is mainly devoted to the study of verbs, ie the rules of verbs, the interpretation of linguistic phenomena related to the chapters of verbs, the translation is compared with the manuscript, and information about the changes and indicators specific to the publication. The letters and their reading table are also included. After the main dictionary, a large-scale article by S. Mutallibov in Volume I was added, as well as comments on Volume II, "The Problem of Tribes," and Volume III, "About Some Tribes." The title page and two pages of the manuscript are also attached.

The third volume is 306 pages. No preface given. It all started with the Fifth Book. At the end of the publication, S. Mutallibov's comments are preserved.

In 2017, a complete edition of the "Diwanu lug'ati-t-turk" based on the translation of $\mathrm{S}$. Mutallibov was published, revised, supplemented and amended [20]. The publication is the result of many years of fruitful research by the world-renowned scholar of Turkish philology, Doctor of Philology, Professor Kasimjon Sodiqov. R. Alimuhammedov noted: "I have personally witnessed that teacher Kasimjon Sodiqov has been working hard on this book for eleven years. An expert who has seen this edition will immediately notice that it is radically different from other editions [21]".

The publication consists of 482 pages, printed in the Krill alphabet as a single book. The introductory part of the work includes an article by K. Sodikov Mahmud Kashgari and his work "Diwanu lug'ati-t-turk" (pages 3-10). This section provides information on Diwan's manuscript, linguistic terms used by Kashgari, and comments on the morphology and phonetics of words. Also included are comments on the principles of Diwan's preparation for publication (pp. 10-11) and the transcription used in the text (p. 12).

This is followed by a transliteration and translation of the manuscript (["TURKISH WORDS DIWAN"] BOOK Compiled by Mahmud bin al-Husayn bin Muhammad al-Kashgari (may Allaah have mercy on him)] (p. 13). PREFACE We do not agree with the opinion that "this book is in the Turkmen language" ... the half-page text, which begins with the sentence, consists of a half-page text. he writes that he asked people about this book.They also came to this land at a 
CURRENT RESEARCH JOURNAL OF PHILOLOGICAL SCIENCES 2(6): 21-28,

May 2021 DOI: https://doi.org/10.37547/philological-crjps-02-06-05

ISSN 2767-3758

(C)2021 Master Journals

\section{Crossref do) 8 Google}

Accepted07thJune, 2021 \& Published 12 thJune, 2021

young age and do not understand the content of the book because they do not know their language well. According to Diwanian researcher S. Rustami, the preface was written by one of the owners of the book [22]. S.Mutallibov and H.Boltaboev's publications do not include this preface, and there is no information.

Then comes the Diwan Introduction (pages 1427 ), the main Dictionary section (pages 28-428). Also included is a page of the preface of the manuscript with the Uyghur alphabet, a map of the Earth drawn by Kashgari, and another page (between pages 192-195). At the end of the book, the Arabic linguistic terms used in the publication are explained. A general conclusion is also included in Russian and English. According to our calculations, the total volume of art samples is 243 (856 lines) [23]. Of these, 185 are quadratic and 58 are binary bytes. The number of proverbs was 298, and 42 proverbs were repeated[24].

- Specific features and general changes to this publication are as follows:

- Diwan is published in one volume;

- S. Mutallibov's foreword and then comments were not included in place of words;

- The text of the preface of the secretary is noted before the introduction;

- The Turkish examples given in the play have been re-transcribed on the basis of the manuscript;

- Famous horses in the Arabic text are given in the transcription;

- In subtle words, after the vowel consonants, vowels and sonores -kä option is selected (ewkä, bizkä);

- Person-number suffixes are given in thin and thick words in the forms -men, -sen (keliglimen, barïrmu-sen);
- Copied to the beginning of the sample and enclosed in square brackets in order to identify some of the words in the sentence or compound in the manuscript: [أَتُلِْى otuldi (ўтулди)] tariğ otuldï - the crop was overgrown, burned.

- Some words and phrases that were mistaken in S. Mutallibov's edition were corrected on the basis of the manuscript: terkineverything collected (not Shosh's name);

Before Kashgari poems (Шоир) шундай деган, (Билимли) шундай деган, (Кўпни куцрган) шундай деган, after the poems translated Айтмоқдаки. In proverbs before proverbs Мақолда (шундай келган), and after proverbs it is translated as Маъноси.

\section{Conclusion}

In preparing both editions, the authors are based on the translation of S. Mutallibov and compared with the manuscript. The text of S. Mutallibov's translation is preserved in the editions of $\mathrm{H}$. Boltaboev and K. Sodikov. However, the peculiarities of the three editions are related to the quotation, the expression of famous names, the quality, quantity, order of the articles, the spelling of the words gained by the content of the text, the transcription.

To date, thousands of studies, translations and publications have been conducted on the Diwanu Dictionary-t-Turk. However, the example of a deep sea full of gems, this monument will still be the basis for many more scientific works. There is a great need for a comparative study of the various translations and publications of the diwan. Indeed, a comparative analysis of different approaches and interpretations is unlikely to reveal the unknown reserves of reality and be the basis for even greater scientific achievements of the scientific community. 
CURRENT RESEARCH JOURNAL OF PHILOLOGICAL SCIENCES 2(6): 21-28,

May 2021 DOI: https://doi.org/10.37547/philological-crjps-02-06-05

ISSN 2767-3758

(C)2021 Master Journals

Crossref do: 81 Google

Accepted07thJune, $2021 \&$ Published $12^{\text {th }} J u n e, 2021$

\section{REFERENCES}

1. Алиев. А Махмуд Кашгари - ученыйэнциклопедист периода ренессанса в государстве караханидова. А. Алиев Вестник КРСУ. 2015. Том 15. No 10/ 12$15 \mathrm{c}$

2. Махмуд ал-Кашгари. Диван лугат аттурк (Свод тюркских слов). В 3-х томах. Т. 1. Пер. с араб. А.Р. Рустамова под ред. И. В. Кормушина [Текст] / Махмуд алКашгари. - М., 2010. - 15.c

3. Ercilasun, A. B., Akkoyunlu, Z. (2014). Kâşgarlı Mahmud Dîvânu Lugâti't-Türk (Giriş - Metin - Çeviri - Notlar - Dizin), Ankara: TDK Yayınları. S.1120.

4. Tamir N. Prof. Dr. Ahmet Bican Ercilasun ve Prof. Dr. Ziyat Akkoyunlu'nun hazirladiklari Dîvânu Lugâti't-Türk adli eser üzerine. Uluslararası Türkçe Edebiyat Kültür Eğitim Dergisi Sayı:3/3 2014 s. 260-276, Türkiye.

5. Ersoy, Feyzi. (2019). "Bir Kitaba Tutuldum! Dîvânu Lügâti't-Türk'ün Romanı" Ankara: Gazi Kitabevi Yay. 2019. S.173

6. Erkan Karagöz . Bir Kitaba Tutuldum. Turk Yurdu. Sayi 380. Nisan. 2019. S. 87-88

7. Chichekli Ali. Kashgarli Mahmut.DIVAN-U LUGAT-IT TURK. May yayinlari genel kultur kitaplari 2. 1970. C 24

8. Mahmud al-Kashgari, Compendium of the Turkic Dialects (Diwan Lugat at-Turk), edited and translated with introduction and indices by Robert Dankoff, in collaboration with James Kelly. Cambridge, Mass. [In: Sources of Oriental Languages and Literatures, ed. Sinasi Tekin.] Part I: 1982 (Pp. xi + 416). Part II:
1984 (Pp. iii + 381). Part III: 1985 (Pp. 337 + microfiche)

9. Гарипов Т.М. Арабские масдары II породы и их рефлекты в башкирском языке // Ак-туальные проблемы контрастивной лингвистики.Уфа : БГУ, 2011.Ч.I ;

10. Содиқов.3. Денкофф Роберт.Бахту тахтга элтувчи билим. Жахон адабиёти. №11 (102) 2005 йил,ноябр. Б. 148-156.

11. А. Алиев. Восточный ренессанс и его роль в историко-культурном развитии кыргызстана и сопредельных территорий (х в. - первая треть xvi в.) Диссертация на соискание ученой степени доктора исторических наук. Бишкек - 2016. с. 166

12. Махмуд Кашгари. Словарь тюркских языков / перевод на кырг. Т. Токоев, К. Кошмоков. Бишкек, 2011. Т. І.с. 906; 2012. T. II. c.591; T. III. c.678

13. Xudoyberdiyev J. Mahmud Qoshg'ariy hayoti va "Devonu lug'otit turk" bo'yicha yaratilgan asarlar ko'rsatkichi. - T.: Akademnashr, 2011. - b. 10.

14. Махмуд ал-Кашгари. Диван лугат аттурк (Свод тюркских слов). В 3-х томах. Т. 1. Пер. с араб. А.Р. Рустамова под ред. И. В. Кормушина [Текст] / Махмуд алКашгари. - М., 2010. - 461 с.

15. Кашгари, М. Дивону лугат ат-тюрк [Текст] / М. Кашгари; пер., предисл. 3.А. М. Ауэзовой. - Алматы: Дайк-Пресс, 2005. - 1288 c.

16. Махмуд Кашгарский. Дивану люгат иттюрк: в 4-х т. . Перевел Рамиз Аскер [Текст] / Махмуд Кашгарский. - Баку: МДМ, 2009.

17. Фитрат. Энг эски турк адабиёти 
CURRENT RESEARCH JOURNAL OF PHILOLOGICAL SCIENCES 2(6): 21-28,

May 2021 DOI: https://doi.org/10.37547/philological-crjps-02-06-05

ISSN 2767-3758

(C)2021 Master Journals

Crossref do) 818 Google

Accepted07thJune, $2021 \&$ Published $12^{\text {th }} J u n e, 2021$

намуналари. Самарқанд. 1927.

18. Махмуд Кошғарий. “Девону луғотуттурк” . 1-3- жилдлар. Таржимон ва нашрга тайёрловчи Муталлибов.С. -Т: ЎзФА Фан нашриёти. 1960, 1961,1963.

19. Махмуд Кошғарий. Девону луғоти-ттурк. 1-3 жилд. (Нашрга тайёрловчилар: А.Рустамов, Х. Болтабоев, Б.Исабеков) -T.: MUMTOZ SO'Z, 2016

20. Махмуд Кошғарий. Девону луғати-ттурк -Т.: Ғафур Ғулом. Нашрга тайёрловчи Содиқов.Қ. 2007. Б.2.

21. Алимухаммедов.Р. Проф. Қ.Содиқов томонидан тайёрланган “Девону луғати-т-турк” асарининг янги нашри // “Девону луғоти-т-турк” - туркий халқларнинг ноёб ёзма ёдгорлиги" мавзуидаги халқаро илмий анжуман материаллари.:Т. 2018. Б. 122.

22. Салима Рустамий. Девону луғоти-ттурк" даги лингвистик атамалар. Тошкент давлат шарқшунослик институти. 2006. - Б.20.

23. Sattorova. Z.I. About Uzbek Editions of Dīwān Lughāt Al-Turk . The American Journal of Social Science and Education Innovations. January 17, 2021 | Pages: 9299

24. Мирзаалиев. И. Қадимги туркий мақоллар семантикаси ва стилистикаси. (“Девону луғоти-т-турк” материали мисолида). Филология фанлари бўйича фалсафа доктори (PhD) диссертацияси автореферати. Т.: 2020. -Б. 14. 